\title{
Effect of Gestagen on Mitosis in the Cultured Mammary Glands of Mice
}

\author{
Isao ITo*, Makoto MoRI**, Yoichi SHodA \\ and Kaoru KoHмoto \\ Department of Animal Breeding, Faculty of Agriculture, \\ University of Tokyo, Bunkyo-ku, Tokyo 113
}

(Received August 8, 1982)

\begin{abstract}
Fragments of mammary glands from mid-pregnant mice were cultured in Medium 199 containing insulin $(1 \mu \mathrm{g} / \mathrm{ml})$, prolactin $(5 \mu \mathrm{g} / \mathrm{m} l)$, and progesterone (200 $\mathrm{nM})$ or its derivatives. The frequency of mitosis was assessed in alveolar cells after treatment with colchicine for $3 \mathrm{hr}$. The mitotic index was increased at $24 \mathrm{hr}$ after the beginning of the culture with progesterone. $20 \alpha-H y d r o x y-4-p r e g n e n-3-o n e$, one of the metabolites of progesterone in the mammary glands, showed stimulatory effect on the mitosis, while $5 \alpha$-pregnane-3,20-dione, one of the metabolites of progesterone in mammary tumors but not in the normal mammary glands, had no significant effects. These results suggested that both progesterone and $20 \alpha$-hydroxy-4-pregnen-3-one are mitogenic for the mouse mammary glands during pregnancy.
\end{abstract}

Jpn. J. Zootech. Sci., 54 (2): 106-109, 1983

Progesterone was metabolized to $20 \alpha$-hydroxy-4-pregnen-3-one in the mammary glands ${ }^{1.2)}$, and to $5 \alpha$-reduced compounds, such as $5 \alpha$-pregnane-3,20-dione, in the mammary tumors ${ }^{2.3)}$ of mice and rats. The metabolism of steroid hormones in their target organs is recognized as an important phenomenon for regulating the potency of the hormones and for diversifying its actions ${ }^{4}$. Although the accumulation of considerable amounts of information on hormonal control of mammary growth, the role of progesterone in this tissue is not clarified yet ${ }^{5)}$. The present study was conducted to elucidate the direct effect of progesterone, $20 \alpha$-hydroxy-4-pregnen-3-one, and $5 \alpha-$ pregnane-3, 20-dione on the mitosis of the mammary glands of mid-pregnant mice by using the fragment culture technique, which was first reported by ELIAS ${ }^{6}$ ) and devel. oped by several groups including our laboratory ${ }^{7}$.

\section{Materials and Methods}

Inbred KA strain mice maintained in our laboratory were used for the experiment on day 7 or 8 of gestation. The mammary glands were exposed by stripping the skin under pentobarbital anesthesia ( $30 \mathrm{mg}$ per animal). After trimming off adhering tissues, approximately 45 fragments of $1 \mathrm{~mm}$ square each were excised from the second thoracic mammary gland laying between the internal and external thoracic arteries.

*Present address; Laboratory Animals Center, Chiba University School of Medicine, Inohana, Chiba 280.

* To whom correspondence should be addressed. 
The tissues were occasionally moistened with Medium 199 during the operation. Three to 5 fragments were randomly distributed into a culture dish, which contained $3 \mathrm{ml}$ of Medium 199. Regimen of Medium 199 with Hanks' salt was modified by diluting $9 \mathrm{ml}$ of 10-times concentrated M 199 (Difco Laboratories, Detroit, Mich., U.S.A.) with $91 \mathrm{ml}$ of $0.2 \%$ sodium bicarbonate which had been autoclaved. Bovine insulin (Ultralente, Novo Industri A/S, Denmark) was dissolved in the medium to achieve the final concentration of $1 \mu \mathrm{g} / \mathrm{ml}(0.12 \mathrm{U} / \mathrm{ml})$. One $\mathrm{mg}$ of ovine prolactin (NH-P-S8) was dissolved in $0.1 \mathrm{ml}$ of $0.1 \mathrm{mM}$ sodium hydroxide and diluted to 5 $\mu \mathrm{g} / \mathrm{ml}$ with the medium. These solutions were filtered through membrane filters (pore size; $0.45 \mu \mathrm{m}$, Millipore Coop., Bedford, Mass., U.S. A.) prior to use. Steroids obtained from Sigma Chemical Co. (St. Louis, Mo., U.S. A.) were dissolved in ethanol and used after dilution with the medium. The final concentration of ethanol did not exceed $0.5 \%(\mathrm{v} / \mathrm{v})$. All the medium was supplemented with Penicillin $\mathrm{G}(50 \mathrm{U} / \mathrm{ml})$. Incubation was performed at $37^{\circ} \mathrm{C}$ under an atmosphere of $\mathrm{O}_{2}: \mathrm{CO}_{2}(95: 5)$. Colchicine $2 \mu \mathrm{g}$ in $0.1 \mathrm{ml}$ of the medium was added into a culture dish $3 \mathrm{hr}$ before termination of the culture to stop mitoses at the metaphase. Each fragment was fixed in Bouin's fixative. Serial paraffin sections of $7 \mu \mathrm{m}$ thickness were stained with hematoxylin and eosin. Mitotic index was expressed as the number of cells at the metaphase per 1,000 alveolar cells. The observation was performed on randomly chosen four sections, each consisted at least 1,000 alveolar cells. Results were analyzed for significance by Student's $t$ test.

\section{Results and Discussion}

In order to investigate the effect of progesterone on mitosis, fragments of the mammary gland were cultured in medium containing insulin $(1 \mu \mathrm{g} / \mathrm{ml})$, prolactin (5 $\mu \mathrm{g} / \mathrm{ml})$, and $200 \mathrm{nM}(63 \mathrm{ng} / \mathrm{ml})$ of progesterone for $5,10,24,48,72$, and $96 \mathrm{hr}$. The results are shown in Fig. 1. In the presence of progesterone, the mitotic index was increased at $24 \mathrm{hr}$ after the beginning of culture $(\mathrm{P}<0.01$ against control at $24 \mathrm{hr}$ ), and then decreased to the control level. This concentration of progesterone is comparable to the level in blood during mid-pregnancy ${ }^{8}$, and an increase of progesterone beyond this concentration depressed the effect (data not shown). The decline of the mitosis after $24 \mathrm{hr}$ of culture is consistent with the study of STOCKDALE and TOPPER ${ }^{9}$, in which they discussed that the mammary gland contain a limited number of cells which produce different daughter cell type after division and these daughter cells do not repeatedly divided during culture.

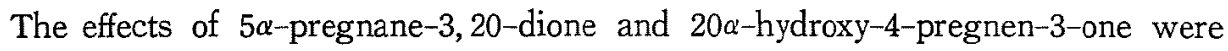
also evaluated from the mitotic index of mammary alveolar cells which had been cultured as a fragment in the presence of insulin, prolactin, and $200 \mathrm{nM}$ of each steroid. A similar pattern as in the case of progesterone was observed in the culture with $20 \alpha$-hydroxy-4-pregnen-3-one, but this steroid had a prolonged effect on mitosis than progesterone itself. Even after $96 \mathrm{hr}$ of cultivation, $20 \alpha$-hydroxy-4-pregnen-3-one was still effective on mitosis $(P<0.01$ at 48 and $96 \mathrm{hr}$, and $\mathrm{P}<0.05$ at $72 \mathrm{hr}$ against 


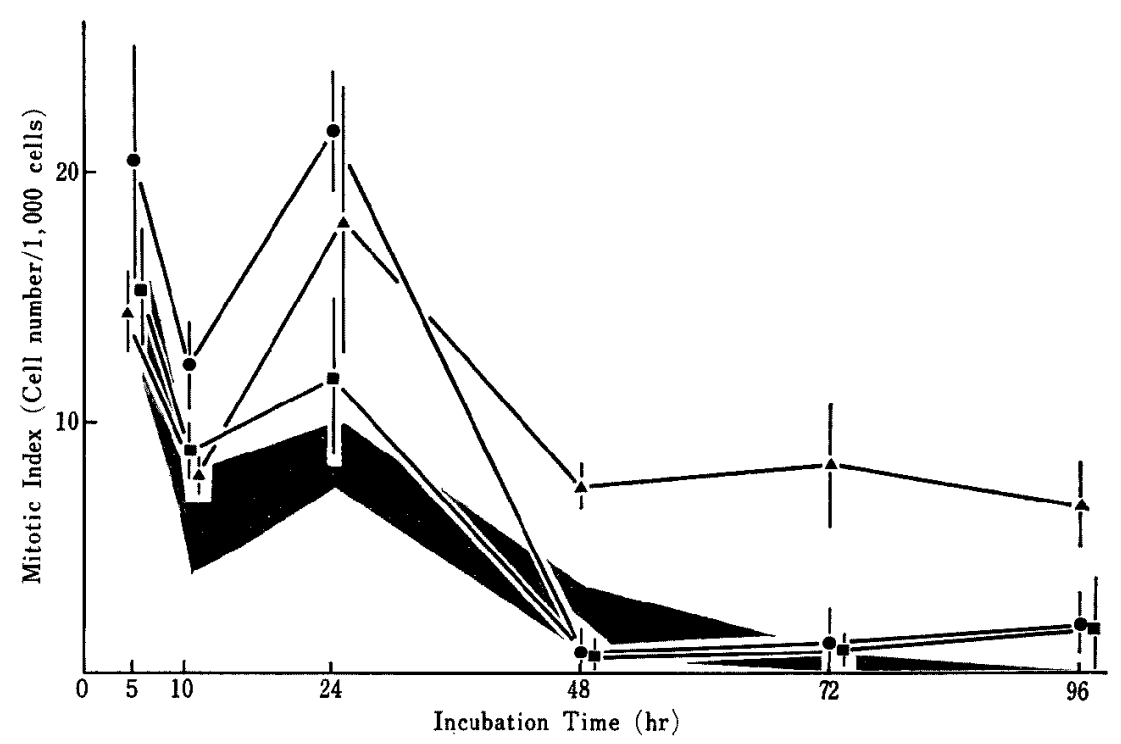

Fig. 1. Effect of various gestagen on mitotic indices of cultured mammary glands of mice. Fragments of the mammary glands were cultured at $37^{\circ} \mathrm{C}$ in Medium 199 containing insulin $(1 \mu \mathrm{g} / \mathrm{m} l)$, prolactin $(5 \mu \mathrm{g})$

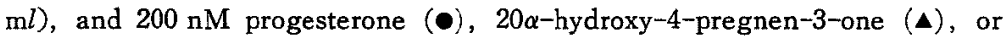
$5 \alpha$-pregnane-3,20-dione (a) in an $\mathrm{O}_{2}: \mathrm{CO}_{2}(95: 5)$ atmosphere. Colchicine $2 \mu \mathrm{g}$ was added $3 \mathrm{hr}$ before the termination of culture. The points and bars represents means $\pm S$. $E$. $(n=4)$. The shaded area indicates mean $\pm S$. E. $(n=4)$ of the control group in which the tissues were cultured with insulin and prolactin.

conttrol). Since $20 \alpha$-hydroxysteroid dehydrogenase was involved in interconversion between progesterone and $20 \alpha$-hydroxy-4-pregnen-3-one ${ }^{10)}$, the prolonged effect of this steroid on mitosis could be explained by its conversion to progesterone during the culture. However, it is not clarified from this experiment that which steroid has the mitogenic activity on the mammary gland.

On the other hand, $5 \alpha$-pregnane-3, 20-dione had no effect on mitosis in this tissue, since the curve was similar to that obtained from the culture without any steroid. There are several reports on the physiological importance of $5 \alpha$-reduction of progesterone. In chick oviducts, progesterone was metabolized to $5 \alpha$-pregnane-3, 20-dione and this metabolite was more active in avidin synthesis than progesterone itself ${ }^{11}$. Nutr and Karavolas ${ }^{12)}$ have also shown the significance of $5 \alpha$-reductase in the neuroendocrine tissues for the feedback effects of progesterone on gonadotropin secretion. On the contrary, in addition to the previous work which showed the absence of $5 \alpha-$ reductase activity in the normal mammary glands ${ }^{13}$, the present study provides evidence that $5 \alpha$-reduction of progesterone is not involved in the mitogenic effect of progesterone in the mammary glands.

The authors are indebted to Toichiro Kondo in this laboratory for his assistance during this experiment. 


\section{Progesterone and Mammary Gland}

\section{References}

1) MORI, M. and B. TAMAOKI, Steroids, 29:517-524. 1977.

2) Mori, M., T. Tominaga and B. Tamaoki, Endocrinology, 102: 1387-1397. 1978.

3) Mori, M. and B. Tamaoki, Eur. J. Cancer, 16: 185-193. 1980.

4) KAO, L. W. and J. WeIsz, Endocrinology, 96: 253-260. 1975.

5) Yokoyama, A. and K. Ota, in Physiology of Mammary Glands. (Yoroyama, A., H. Mizuno and H. Nagasawa, eds.) 265-284. Japan Scientific Society Press \& University Park Press. Tokyo \& Baltimore. 1978.

6) EliAS, I. J., Science, 126: 842-844. 1957.

7) Iro, I., in preparation.

8) Kuhn, N. J., J. Endcrinol., 44: 39-54. 1969.

9) Stockdale, F. E. and Y. J. Topper, Proc. Nat. Acad. Sci. U. S. A., 56: 1283-1289. 1966.

10) Mori, M. and W. G. WIEST, J. Steroid Biochem., 11: 1443-1449. 1979.

11) Strott, C. A., Endocrinology, 95: 826-837. 1974.

12) Nuti, K. M. and J. Karavolas, Endocrinology, 100: 777-781. 1977.

13) Тамаокі, B. and M. Mori, J. Steroid Biochem., 11: 227-230. 1979.

\section{マウス培養乳腺の細胞分裂に対するゲスターゲンの効果}

\section{伊藤勇夫・森誠・正田陽一・河本 蹯}

東京大学農学部, 東京都 113

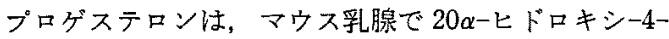
プレダネンー3-オンに代謝されるが，乳癌では主に $5 \alpha-$ ブレグナン-3,20-ジオンに代謝される. 本研究は，乳腺 の細胞分裂に対するプロゲステロンおよびその代謝産物 の効果を調ベるために，乳腺の器官培養を用いておこな ったるのである. 用いた秏腺は，妊娠中期の雌、ウス (KA 系)より得た. $1 \mathrm{~mm}$ 角の乳腺組織片をインスリン $(1 \mu \mathrm{g} / \mathrm{m} l), \quad$ ブロラタキン $(5 \mu \mathrm{g} / \mathrm{m} l)$ および各種のゲ スターダン $(200 \mathrm{nM})$ を含さM199 合成培養液中で，温 度 37 度，95\%酸素 $5 \%$ 孷酸ガスの気相のもとで培養し た. 培亶終了 3 時間前にコルヒチン $(2 \mu \mathrm{g})$ 索添加し, 細 胞分裂を停止させ，乳腺胞細胞に分裂中期像の現われる
頻度安計数した．その結果，プロゲステロンを加えて培 養したものの方がインスリンとプロラクチンのみを含え だ培養液中で培養した乳腺よりも，培養開始 24 時間後 に分裂の頻度が上昇していた．5 $\alpha$ ープレダナン -3,20-ジ

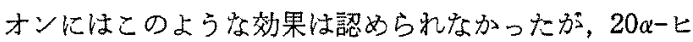
ドロキシー4ープレグネンー3ーオンは 24 時間後ではプロゲ ステロンと同程度の分裂促進効果があり，この効果は培 養開始 96 時間まで持続していた，以上の結果は，奻娠

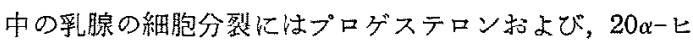
ドロキシー4ープレグネンー3-オンが関与している可能性定 示唆している.

日畜会報，54(2)：106-109，1983 